\title{
Pembangunan Ekonomi Pedesaan (Studi pada Sebuah Inovasi dan Realisasi Ekonomi Desa Banmaleng Gili Raja Sumenep Madura)
}

\author{
Misbahul Munir, Ach Faqih Supandi \\ IAIN Jember, Universitas Islam Jember \\ Email: mmunir@iain-jember.ac.id, achfaqih795@uij.ac.id
}

\begin{tabular}{l}
\hline Article Info \\
\hline Article history: \\
Published: June 28,2021 \\
Page: 112 - 121 \\
\hline
\end{tabular}

Keyword:

The development of

Economic, Village Economy and the Innovation and Realization of Village Economy

\begin{abstract}
Metode penelitian ini menggunakan metode kualitatif deskriptif. Hasil dari penelitian ini adalah dalam penerapan perekonomian desa-desa tentunya nilai kekeluargaan yang masih kental di pedesaan harus semakin ditingkatkan serta dipegang teguh sebagai panduan dan batasan agar tidak terjadinya pergesekan Antara anggota desa (perangkat desa) dan masyarakat desa itu sendiri. Dengan kelembagaan atau kebiasaan yang telah ada, maka masyarakat pedesaan biasanya dapat melakukan kerja sama tanpa ada pergesekan yang cukup berarti sehingga menimbulkan persaingan tidak sehat dalam peningkatan ekonomi masyarakat desda tersebut.
\end{abstract}

Kata Kunci : Pembangunan ekonomi, Ekonomi Desa dan Inovasi dan Realisasi Ekonomi Desa.

This research method used descriptive qualitative methods (Qualitative Research).The results of this study were in the application of the village economy, the family values that were still thick in the villages must be further enhanced and adhered to as a guide and boundaries so there was no friction between village members (village officials) and the village community itself. With existing institutions or habits, rural communities were usually able to cooperate without significant friction which results in unfair competition in the economic improvement of the village community.

Keywords : The development of Economic, Village Economy and the Innovation and Realization of Village Economy.

Copyright (C) 2021 OECONOMICUS Journal of Economics

\section{Introduction}

A country can be said to be prosperous if the economic development in the country runs smoothly, this can be predicted through urban development within the country. The development of economic

\section{Editorial Office:}

Prodi Ilmu Ekonomi Fakultas Ekonomi dan Bisnis Islam, UIN Sunan Ampel Surabaya

Jl. Ahmad Yani 117 Surabaya, Jawa Timur 60237, Indonesia.

Email: oje@uinsby.ac.id 
should not only be in urban areas but in rural areas so that development within a country continues to run and is equitable in accordance with the concept of economic development in essence.

National development will be said to be smooth if it is able to cover the lowest level, namely at the rural level or remote villages that are rarely touched by the government as a whole. This is done in order to change a society's view of the government which only sees one side. Farmers, fishermen and farm workers need to change their perspective on the government with an economic development approach that starts from a village or an island.

The village is a legal entity in which a community resides from the government itself. Besides, the village can be said to be the embodiment or unity of geography, social, economy, politics and culture that is contained in the village itself (an area). The influence and relationship are reciprocal with other areas. A village is still very difficult to develop. This problem does not mean they do not want to develop, but something new is sometimes still contrary to the habits or customs of the village. This happens because of the teachings of the ancestors from a village so that they still held fast to the teachings they had followed for a long time.

Village is another designation for urban residents for a residential area that is not located in cities or central areas consisting of small settlements. The life of rural communities is different from those who live in urban areas, as well as economic differences between rural and urban communities.
In a village, some facilities such as hospitals, schools, pharmacies or adequate educational infrastructure and technology are very affordable in the village. The village community still uses the services of a dukun (either a dukun beranak or a paranormal) who are usually asked for help in the village. In terms of health, maybe only the puskesmas are in the village but that doesn't mean they exist in every region. As well as education, there is still a lack of educational facilities in a village in one sub-district, sometimes it is only one or two schools. The difficulty of incoming assistance is from the government to build schools in rural or island areas and sometimes teachers rarely want to teach in rural areas due to access to that village. It is very difficult and requires a long time.

The low level of community income is the main problem, which dominates all problems in rural areas. In addition, the high number of children dropping out of school, infant, maternal mortality, disease outbreaks ranging from malaria, cholera, typhus and dengue fever. All of them are caused by the low economic level of income of rural communities. Children grow up without proper education and even without the attention of parents, so they are prone to become naughty and easily under the influence of delinquency, even prone to committing crimes that lead to criminal acts. The development of village will be increasingly challenging in the future with regional economic conditions that are increasingly open. Also, the political life is polemic increasingly. However, until now the village has not been able to move on from its old profile, namely 
underdevelopment and underdevelopment in any aspect. Even, the village has a very big role in the development of the city itself, but the village is still looked down upon in terms of the economy or other matters. This view is consciously or unconsciously within each individual, even though we know that most of the Indonesian population lives in rural areas and works as small farmers (very limited land). Therefore, it is only natural that rural development should be a top priority in every development strategy and policy in Indonesia. If this is not considered thoroughly, the gap between life in the city and in the village will be even higher, especially in terms of the economy (Mubyarto, 2004).

An approach to economic development comes from rural areas by integrating the existing rural culture, good habits, which need to be repackaged, combined with an economic concept that is easily understood by the rural community. The mutual cooperation system as a cultural root that has long been in the hands of the community needs to be revived and revived as a support and driver of progress in rural areas. It combines with a better management system so that it can help accelerate the development of the village, especially in terms of the economy.

As it is known, the agricultural activities in the village are very diverse. The characteristics of economic activity in a region can basically be divided into three growth sectors (Soedrajat, 1997), they are: (1) the primary growth sector, namely the sector or economic activity that creates rapid growth and creates expansion forces to various other sectors in the economy, (2) a supplementary growth sector, namely a sector that develops rapidly as a direct result of developments in the primary growth sector, and (3) a related growth sector, namely a sector or economy that develops in tune with an increase in income, population and production in the industrial sector.

Economic development programs in rural areas must be considered very well and carry out. Moreover, it still has to pay attention to factors that may occur in the village polemic itself, such as funding which must avoid mistakes in the management of the village funds. The reason is human resources in rural areas are still not ready for rural economic development. It is very necessary to provide assistance from people who are professional and have been trained or have been equipped with sufficient knowledge and experience and can understand the program so that rural economic development very much in accordance with the level of economic development in essence.

Based on the above background, the researcher needed to do some research related to village economic development and must limit the scheme from the scope of the discussion so that it does not get out of the research and writing order in actual written works..

\section{Theoretical Framework}

According to Todaro (1997), economic development is part of development. Meanwhile, development itself can be interpreted as a multidimensional process involving major changes in social structures, accustomed mental attitudes, and national institutions 
including the acceleration of economic growth, reduction or eradication of real poverty.

The development of economic can be defined as: a branch of economics that aims to analyze the problems faced by developing countries and find ways to overcome these problems so this country can build their economy more quickly.

Although the development of economic policies are aimed at increasing welfare in the broadest sense, economic development activities are always seen as part of the overall development effort carried out by a society. The development of economic only includes the efforts of a community to develop economic activities and increase the income of the people, while all development efforts include social, political and cultural development efforts. Then, the notion of economic development is generally defined as a process that causes an increase in the per capita income of a community in the long term (Muhammad Hasan, 2018).

The development of rural economic has several points of view, including according to Haeruman (1997), there are two points of view to be able to study the countryside, namely:

1. Rural development is seen as a natural process that rests on the potential and capabilities of the village community itself. This approach minimizes the interference of questions from outside, so the expected changes take place over a long period of time.

2. The other side is rural development as an interaction between the potentials possessed by rural communities and is pushed from outside to accelerate rural development.

The main objective of rural development is the creation of a strong economic condition of the people in rural areas, capable of growing independently and sustainably. These rural development targets are pursued in stages with the following steps: first, improving the quality of the workforce in rural areas; second, increasing the capacity of village government officials; third, strengthening government institutions and village community institutions; fourth, development of the socio-economic capacity of rural communities; fifth, development of rural facilities and infrastructure; and sixth, consolidating integrated village development with an environmental perspective.

The rural development approach should have started to be directed integrally by taking into account the uniqueness of the region, both in terms of conditions, potentials and prospects of each region. However, in the formulation of rural development policies, it can be seen in three groups (Haeruman, 1997), namely:

1. Policy is indirectly directed at creating conditions that ensure the continuity of every rural development effort that supports socio-economic activities, such as the provision of supporting facilities and infrastructure (markets, education, health, roads, etc.), institutional strengthening, protection of activities and socio-economic community through law. 
2. Policies that are directly directed at increasing the economic activities of rural communities.

3. Special policies reach the public through special efforts, such as guaranteeing the law through legislation and guaranteeing, the safety and comfort of the community.

In addition, rural development policies must be implemented through sectoral and regional approaches. A sectoral approach in planning always begins with a statement regarding what sectors need to be developed to achieve development goals. This is different with the sectoral approach. The regional approach focuses more on which areas need to be prioritized for development, then what sectors are appropriate to be developed in each region. In fact, the regional approach is often taken not in the framework of totality, but only for certain areas, such as underdeveloped areas, border areas, or areas that are expected to have a strategic position in the politicaleconomic sense. The intended direction is a combination of sectoral. Also, the regional approaches and development must always be linked with the sectoral and spatial dimension.

According to Faisal Kasryno (1983), the village institutional economy is a set of rules that govern or bind and are obeyed by the community. These rules determine the procedures for cooperation and coordination of community members. Rural institutions can be in the form of land tenure institutions, work relations institutions, and credit institutions.

Then, according to D. Ricardo (1966), in an economic society there are three groups of people, namely the capitalist group, the labor group and the landlord class. The main class is a group that leads production and plays an important role because they seek profit. When the working class, he said that it was dependent on the capitalist class and it was the largest group in society. As for the landlord class, they only receive rent for the land area that they rent out.

In brief, a new economy can be said to be developing if the per capita income shows an upward trend. However, it does not mean that per capita income will continue to increase. The existence of an economic recession, political turmoil, and export decline, for example, can cause an economy to experience a decline in its level of economic activity. If this situation is only temporary, and economic activity increases on average from year to year, then the community can be said to be experiencing economic development.Therefore, the higher the level of income per capita is from a country. The more successful the country is in carrying out its development. Thus, development here is defined as the total wealth of a country (Arief, 1995).

\section{Previous of Research}

Directorate of Settlements and Housing, Study of Village Economic Development to Overcome Poverty was used in this research as primary data collected. It was based on the results of interviews and discussions on target targets, such as government agencies, leaders and communities. The secondary data contained the regional conditions, regional economic conditions, village potential, socioeconomy, and village institutions. In this research, there were two analytical 
approaches used, namely quantitative analysis which was carried out using the tabulation approach and trend analysis, and qualitative analysis that used the descriptive analysis approach (methods related to the collection and presentation of a cluster of data) so was provides useful ones. The results of this study were from these conclusions in this research recommendation: (a) The need to increase the capacity of human resources, (b) The creation and development of existing economic institutions, (c) Evaluating the regulations that related with society villages, (d) The need for government initiatives to encourage and find alternative livelihoods in rural communities.

\section{Methodology}

This research used the descriptive qualitative research. It was more focus on social phenomena from the participant's perspective. Qualitative research is also research that is shown to describe and analyze phenomena, events, social activities, attitudes, beliefs, perceptions, individual or group thoughts (Nana Syaodih Sukmadinata, 2005: 99). According to Kasiran, qualitative research is a particular tradition in social science, which fundamentally relies on observing humans in their own domain and relating to them in their language and events. Meanwhile, according to Sudarto, qualitative research is a research procedure that produces descriptive data in the form of written or spoken words from people or actors that can be observed (Moh Kasiran, 2010: 175).

\section{Discussion \\ The Economic Concept of Rural Development}

The development of economic could be consciously implemented. This could be done by prioritizing the application of the "big push" policy in the form of complementary investments or the "balance" element. It was important to know the concept of balance, because this concept could mean various kinds that do not necessarily coincide with one another.

The main needs strategy stated that the economic development program should be implemented with due regard to the basic needs of the people. The main needs included the main needs of the family for personal consumption, such as food, shelter and clothing, as well as the provision - by the community - of essential services such as drinking water, sanitation, public transportation, health and education facilities. This strategy reinforced the old policy that pays first attention to rural development, erodes social and economic inequality, and provided infrastructure for basic social services such as health and general education.

The term village economic development was often identified with agricultural development. This was because many rural areas (especially in developing countries) had the majority of the population working in the agricultural sector. However, the indicator of village economic development was not only agricultural development. There were so many things that must be considered to build a village, indicators of economic development in the village included: 
1) Good Village Infrastructure. The first thing that became an indicator of village economic development was seen from the rural infrastructure itself, especially in access roads around the village. There were several villages that have easy roads for various types of vehicles to pass, but there were also villages that had poor road access and were difficult for large vehicles to pass.

2) Adequate Public Facilities. To support village economic growth, it must also be supported by adequate facilities from the village. This facility supports all aspects of community life or village residents made it more advanced. The various facilities needed include adequate market facilities, schools, health centers and so on.

3) Access to Information. One of the supporters of village economic development is information. Good access to information can advance the village economy because villagers can learn from other villages or even cities. So that what has been successfully placed in other areas can be tried in that village. Indicators of village economic development can be seen how the information entered in the village. Whether it is good or not, it is very rare to find a village with minimal access to information but which can develop rapidly. On the other hand, villages that have easy access to information will develop quickly.
Therefore, access to information is very important to have.

4) Superior Quality of Human Resources. The next success indicators can be seen from the quality of human resources produced. Are these human resources superior or lacking, for example from the level of education or employment. Villages that are developed tend to have communities with high levels of education. Meanwhile, villages that are less developed and even underdeveloped have people who do not know the importance of education.

5) Resident Income. The last indicator of village economic development is the income of the population, whether the income is appropriate or still far below average. The village is said to be advanced when the income of the population is above average and the village is said to be left behind if the income of the population is still far from sufficient (20 February 2019).

In the economic concept of development, local governments needed to involve themselves in supervision and preparing all regulations in running the business. Thus, it was very necessary for local governments to establish a business entity in which this business entity became the parent in all business fields. These business entities could be in the form of cooperatives, community business units or other business entities. Meanwhile, the asset capital from the village business entity could come from the government or the village fund itself. The 
activities of the village unit cooperative could drive the economy in the countryside. With this activity, the community became a member of the village unit cooperative, so the activity run according to the available provisions. In brief, the rural economy or rural economy would be raised by the presence of productive activities.

The people whose economic level was middle to lower, they could or are classified as poor communities, so the main and mandatory fees could be covered by the local government with the aim of the community being a member of the village unit cooperative. The government funds were paid-up as the basic capital of the Village unit cooperative, so the mandatory contribution fund and the community principal fee could become one that will become the initial capital for the establishment of the Village Unity cooperative.

Village economic development policies must be implemented through sector and regional approaches. The planning of sector approach started with a statement regarding what sectors need to be developed in order to achieve development goals. Besides, the regional approach focused more on which areas need to be developed in each region. In fact, the regional approach was not often taken in the context of totality, but only for certain areas such as underdeveloped areas, border areas or areas that were expected to develop economic strategic positions in the political economic sense. The intended direction was a combination of sector and regional approaches. Also, the regional development should always be linked to the spatial dimension.

The arrangement of rural areas must be adjusted to the existing economic activities of the region concerned. Rural areas were areas that have the main activities in the agricultural sector, including the management of natural resources with the arrangement of the functions of the area as a place for rural settlements, government services, social services, and economic activities. Therefore it could be said that developing agriculture was essentially building the village economy itself.

The Innovation and Actualization of Economic at Gili Raja Island in Improving the Community of Economy

Population growth which continued to increase in number from year to year invites how the creativity of the village community was highly demanded to meet their economic needs. The economic turned over of rural communities, which initially only focused on exploiting land for agriculture alone. Then, the innovation of rural communities there could be various ways to be able to exploit their agricultural land, so the community of economic innovation could run and competed in the five urban economies.

The village economy in the village of Banmaleng, Gili Raja Island was quite interesting and innovative, both in the field were income or from fulfilling the economy every day. Many of these innovations had been carried out by village communities, whether their jobs were agricultural laborers, fishermen laborers or entrepreneurs who were gathered in the village. The formation of an economic system could be said to be 
unique and it did not depend on bank or nonbank financial institutions in its regulation. The income of a village community was motivated by a bank or non-bank financial institution so that the economic system or regulation of the community increased and could meet various needs both per capita income and it was as a whole. The village community, which was actually still included in a small island, was also supported by BUMDES which was currently running in such a way as to help the economy of the people of the middle to lower level, so that the economy of the community could be helped and a decent life in society could be obtained.

The BUMDES application in Banmaleng village was directly managed by the local village head together with the village officials. The management included: community productive businesses, cooperative savings and loans and productive assistance. Of the three components carried out by the local village, it supported the economy of the community whose economic level was middle to lower. The productive assistance activity carried out by the village head was to distribute aid that was productive in nature, not just consumptive in nature. So the assistance was in the form of providing business capital for people who did not have a regular (monthly) income so that people could manage funds as well as possible so that they met their daily needs. The activities were almost the same as the productive efforts carried out by the village head, but the difference between this activity and productive assistance activities was that if productive assistance was provided the fund to people who did not have a business. The productive business was business assistance for people who already had a business but were already close enter the bankruptcy or loss category. The purpose of the activities of the local village head was to help improve the economy of the local village community so that the economy of the community whose economic level could be classified as middle and upper class. In addition, the activities carried out also aim to save misappropriation of village funds from various parties who could not be trusted to manage them productively.

Based on the reality that occurs, the people of Banmaleng village were classified as sufficient in meeting their economic needs and could compete in urban areas. This could not be separated from the intervention of the village head as the control holder of the village government system and allocating village funds based on target and their portion. Then, the village community could be presented that the economy of the village community could be organized with an appropriate system.

Optimization of land in rural areas was developed according to the texture, character and potential that came from natural resources in the village. Starting from livestock, fisheries, small and medium enterprises which were the main targets developed by many rural communities to encourage an increase in their economic needs.

In the application of the village economy, the family assessed that it was still thick and the villages must be further enhanced and upheld as a guide and boundaries so that there was not friction 
between village members (village officials) and the village community itself. With existing institutions or habits, rural communities were usually able to cooperate without significant friction which results in unfair competition in the economic improvement of the village community.

\section{Conclussion}

More intense attention is needed from the government, both through education and provision of policies that benefit rural communities so that their economies can revive. It is not only from the government who has the obligation and role in improving the village economy, but all village communities are expected to synergize. Also, it want to continue in learning to understand the patterns suggested by the government in order to achieve an increase in the production of rural communities which will create equitable prosperity.

\section{Referencess}

Arief, Sritua. 1997. Koperasi Sebagai Organisasi Ekonomi Rakyat, dalam Pembangunanisme dan Ekonomi Indonesia. Pemberdayaan Rakyat dalam Arus Globalisasi. Jakarta: CSPM dan Zaman.

Baswir, Revrisond. 1997. Agenda Ekonomi Kerakyatan. Pustaka Pelajar: Yogjakarta.

Kasryno, Faisal. 1983. Prospek Pembangunan Ekonomi Pedesaan Indonesia. Jakart: Yayasan Obor Indonesia.

Haeruman, H. 2000. "Peningkatan Daya Saing Industri Kecil untuk Mendukung Program PEL". Makalah Seminar Peningkatan Daya Saing. Jakarta: Graha Sucofindo.

Hakim, Abdul. 2004. Ekonomi Pembangunan, Cetakan kedua,
September. Yogyakarta: Ekonisia.

$\begin{array}{ccr}\text { Kartasasmita, } & \text { Ginanjar. } & 1996 . \\ \text { Pembangunan } & \text { Untuk } & \text { Rakyat: } \\ \text { Memadukan. } & \text { Pertumbuhan } & \text { dan }\end{array}$

Pemerataan. Jakarta: Cides.

Mubyarto. (2004), Pembangunan Pertanian dan Penanggulangan Kemiskinan, di Presentasikan pada Workshop "Agriculture Policy for The Future", Jakarta UNSFIR.

Mubyarto. 2000. Membangun Sistem Ekonomi, Yogyakarta: BPFE.

Moh Kasiran. 2010, Metodologi Penelitian Kualitatif-Kuantitatif, Malang: UIN Maliki Press.

Nana Syaodih Sukmadinata. 2005. Metode penelitian Pendidikan, Bandung: PT Remaja Rosdakarya.

Rahardjo, Adisasmita. 2013. Teori-Teori Pembangunan Ekonomi. Yogyakarta: Graha Ilmu.

Solihin Dadang. 2007. Ekonomi Pembangunan Overview Indonesia Masa Kriswas 1998, Jakrta: PT. Artifa Duta Prakasa.

Todaro, Michael P. Economic Development, semua edisi. AddisonWesley Publishing Company.

Todaro, Michael P. dan Stephen C. Smith. 2004. Pembangunan Ekonomi di Dunia Ketiga. Edisi ke 8.

https://www.berdesa.com/perbedaanekonomi-masyarakat-desa-dan-kota/

http://www.scribd.com/doc/13619836/Mem bangun-Desa-Membangun-Indonesia

http://fakhrizajanuardi.blogspot.com/2011/0 7/teori-ekonomi-kesejahteraan.html 